\title{
MICROPROPAGATION AND EVALUATION OF GENETIC STABILITY OF FOXGLOVE TREE (Paulownia tomentosa)
}

\author{
Hassan, K.M. ${ }^{1,}$, A.M. Hosni ${ }^{1}$, M. Hewidy ${ }^{1}$ and
}

\author{
A.B. Abd El razik ${ }^{2}$
}

1- Horticulture Dept., Fac. of Agric., Ain Shams Univ., P.O. Box 68, Hadayek Shobra 11241, Cairo, Egypt

2- Genetics Dept., Fac. of Agric., Ain Shams Univ., P.O. Box 68, Hadayek Shobra 11241, Cairo, Egypt

\section{*Corresponding author: karim_hassan84@yahoo.com}

\begin{abstract}
This reasearch work aimed to fine-tune micropropagation of Paulownia tomentosa in addition to assessing the genetic stability of in vitro raised clones from it. Paulownia tomentosa explants were surface sterilized using clorox (commercial bleach $5.25 \%$ sodium hypochlorite) at 10, 20, 25 and $30 \%$ $+0.5 \mathrm{~g} / \mathrm{l}$ mercuric chloride $\left(\mathrm{HgCl}_{2}\right)$ at different duration times, i.e. 10, 15, 20 and $25 \mathrm{~min}$. In the multiplication stage, shoots were transferred to MS medium at $3 / 4$ strength containing BAP and Kin each at $(0,0.5,1,2$, and $4 \mathrm{mg} / \mathrm{l})$. Whereas, the rooting medium was MS medium at $3 / 4$ strength with IBA and NAA treatments each at $0,0.5,1,2$, and 4 $\mathrm{mg} / \mathrm{l}$. Sterilized explant with $30 \%$ Clorox for $20 \mathrm{~min}$ recorded highest survival percentage. The treatment of Kin at $4 \mathrm{mg} / \mathrm{l}$ gave higher significant shoot length. Whereas BAP application at 2 and $4 \mathrm{mg} / \mathrm{l}$ gave highest significant value of both shoot number and leaf number. Both IBA and NAA at 0.5 or 1 $\mathrm{mg} / \mathrm{l}$ gave highest significant root number/shoot. Whereas, auxin at $4 \mathrm{mg} / \mathrm{l}$ gave highest significant root lengths. Young plantlets resulted from in vitro were acclimitized successfully in a mixture of peat moss: perlit (2: 1) by volume that showed $85.93 \%$ survival.

The genetic stability of in vitro raised Paulownia tomentosa clones was assessed by using intersimple sequence repeats (ISSRs) markers. All of the three ISSR primers screened, produced clear, reproducible and scorable bands.
\end{abstract}

The molecular size of Polymerase Chain reaction (PCR) products generated 22 fragments by these ISSR ranged from $\approx 460$ to $18660 \mathrm{bp}$. All banding profiles from micropropagated plants were monomorphic and similar to those of the mother plant, indicating $100 \%$ similarity. This confirmed the true to type nature of the in vitro raised clones.

Keywords: Paulownia (foxglove tree - princess tree), Micropropagation, Genetic stability.

\section{INTRODUCTION}

The genus Paulownia from the family Scrophulariaceae includes 9 species of trees indigenous to China and East Asia Zhu et al 1986. Most species of Paulownia are fast growing as the harvesting of wood begins within 8-10 years and can continue yearly for as long as is desired. The tree is extremely hardy and its plantation requires only minimal inputs from the grower. Recently, Paulownia intercepted large interest due to variable uses and applications of different parts of it. The value of Paulownia as a short-rotation woody crop plants was reported by Bergmann and Moon, 1997 in afforestation by Zhu et al 1986 and in mine site reclamation by Carpenter, 1977 The wood of Paulownia is soft, lightweight with excellent machining and finishing properties Akyildiz and Shahin, 2010. Its bark has been used in Chinese herbal medicine as a component for remedies of some infectious diseases. Aside from their timber products, some Paulownia species have also an ornamental use Puxeddu et al 2012; Ben Bahri and 
Taoufik, 2013. Propagation of Paulownia tree was limited to seed and root cuttings. Both methods represent low production rates. The use of in vitro propagation techniques provides healthy, homogeneous planting stock for afforestation and woody biomass production as in the case of Paulownia. Efficient vegetative micropropagation protocols have been established over seedling production of Paulownia spp. Bergmann and Moon, 1997; Bergmann, 1998; Rout et al 2001.

Markovic et al (2013) mentioned that in vitro culture was successfully established using disinfection of nodal segments with $0.1 \% \mathrm{HgCl}_{2}$ for 10 min. Immersion in $30 \%$ solution of sodium hypochlorite for 15 minutes to sterilized Paulownia seeds removed surface contamination. Shtereva et al (2014). Chunchukov et al (2015) ascertained that sterilization procedure was performed by washing in tap water with liquid detergent for 20 minutes and subsequently treated with a solution of mercuric chloride $(0.1 \%)$ for 3 minutes followed by rinsing 3 times for 5 minutes with sterile distilled water reduce contamination and increase survival rate. Rout et al (2001) sterilized nodal explants by washing them in $0.1 \%(\mathrm{v} / \mathrm{v})$ detergent "Teepol" (Qualigen, India) solution for $15 \mathrm{~min}$ and subsequently rinsed in running tap water. Further, the explants were disinfested in $0.1 \%(\mathrm{w} / \mathrm{v})$ mercuric chloride $\left(\mathrm{HgCl}_{2}\right)$ solution for $15 \mathrm{~min}$ and then rinsed three times in sterile distilled water.

Shoot proliferation is induced by application of cytokinins at the multiplication stage. Taha et al (2008) reported superiority of BAP over other cytokinins for multiple shoots formation in Paulownia. Lobna et al (2008) tested the effect of BAP and various light intensities upon $P$. kawakamii in vitro proliferation. The medium with $1 \mathrm{mg} / \mathrm{l} \mathrm{BAP}$ was the best for in vitro proliferation. Ben Bahri and Taoufik (2013) found that Shoot proliferation was induced by the mean of MS medium containing different concentrations of BAP (1or $2 \mathrm{mg} / \mathrm{l})$. Shoot proliferation was effectively induced using cytokinins in combination to different type of auxins.

Ipekci et al (2001) and Litwinczuk and Bochnia (2012) reported that MS medium supplemented with $1.0 \mathrm{mg} / \mathrm{l} \mathrm{BAP}$ and $0.1 \mathrm{mg} / \mathrm{l} \mathrm{NAA}$ was optimum to regenerate multiple shoots in Paulownia from shoot tip explant. Also, Rahman et al (2013) showed that $2.5 \mathrm{mg} / \mathrm{l} \mathrm{BAP}+0.5 \mathrm{mg} / \mathrm{l} \mathrm{NAA}$ showed highest shoot induction. At same year, Markovic et al (2013) mentioned that MS medium supplemented with $6 \mathrm{mg} \mathrm{l}-1 \mathrm{BA}$ and $0.5 \mathrm{mg} \mathrm{l-1} \mathrm{IBA}$ gave the best multiplication rate.
At rooting stage of Paulownia, Taha et al (2008) observed that microshoots transferred to half strength MS with $1.0 \mathrm{mg} / \mathrm{NAA}$ gave best rooting rate. Roy (2015) Shoots rooted well in half strength MS supplemented with $2.0 \mathrm{mg} / \mathrm{l}$ NAA. Markovic et al (2013) reported that rooting percentage was $95 \%$ on MS medium with $0.8 \mathrm{mg} / \mathrm{l}$ of IBA or NAA. Lobna et al (2008) stated that microshoots derived from multiplication stage were separated and transferred to a rooting medium having half strength MS medium supplemented with two concentrations (1.0 and $0.5 \mathrm{mg} / \mathrm{l})$ of IAA, IBA or NAA.

For acclimatization plantlets were transferred to small plastic pots containing a mixture of peat and perlite 2:1 v/v by Shtereva et al (2014). Zayova et al (2011) reported that the highest survival percentage (100\%) existed in the plants grown on a mixture of peat:perlite in a $2: 1$ ratio in a greenhouse. They were characterized by rapid growth and development.

All banding profiles from micropropagated plants were monomorphic and similar to those of the mother plant were previously reported by Martin et al (2004) in almond, Joshi and Dhawan (2007) in Swertia chirayita and Abd elrazik (2012) in Paulownia tomentosa.

\section{MATERIALS AND METHODS}

This work was carried out in the Tissue Culture Laboratory, Ain Shams Center for Genetic Engineering and Biotechnology (ACGEB), Faculty of Agriculture, Ain Shams University, Egypt during the period of 2013-2018.

- Culture media: Murashige and skoog (1962) medium (MS) was used in the different in vitro growing stages. Carbon and energy source was $3 \%$ of sucrose. Also, $8 \mathrm{~g} / \mathrm{l}$ agar was added as a solidified agent of media at all stages. The medium was adjusted to $\mathrm{pH} 5.7 \pm 0.1$ and autoclaved at $121^{\circ} \mathrm{C}$ and $1.2 \mathrm{Kg} / \mathrm{cm}^{2}$ for $20 \mathrm{~min}$ before being used. The hormonal supplements were differed according to the requirement of the specified experiments as will be mentioned later. Jars $150 \mathrm{~cm}^{3}$ size filled with about $25 \mathrm{~cm}^{3}$ medium were used at all stages.

-Culture incubation conditions: Culture of all experiments were incubated at $28 \pm 2^{\circ} \mathrm{C}$ and exposed to 2000-2500 lux for 16 hours light using fluorescent lamps (2 lamps per shelf) alternated with 8 hours dark. Each treatment of Paulownia tomentosa comprised three replicates, with three explants per jar for each replicate. 
(Paulownia tomentosa)

- Experimental plants: Shoot tips from Paulownia tomentosa tree from a three years old Paulownia tree, grown at Ain Shams Center for Genetic Engineering and Biotechnology (ACGEB), Faculty of Agriculture Ain Shams University, were chosen as a source of explants for the experiments.

- Establishment stage: Healthy terminal vegetative growth part of $2.5-3$ in length containing the shoot tip and 2-3 lateral buds were collected as explants. Then, the collected explants were defoliated and cleaned with liquid soap and rinsed with a continuous flow of tap water for an hour. Afterwards, they were surface-sterilized using clorox commercial bleach $(5.25 \%$ of sodium hypochlorite $\mathrm{NaOCl})$ at 10, 20, 25 and $30 \%+0.5 \mathrm{~g} / \mathrm{l}$ mercuric chloride $\left(\mathrm{HgCl}_{2}\right)$ for $10,15,20$ and $25 \mathrm{~min}$. After four weeks survival percentage was calculated.

- Multiplication stage: Microshoots resulting from the establishment stage containing 3-4 nodes were taken for the multiplication experiment. Defoliated microshoots were cultured in the multiplication medium which was supplemented with cytokinins either BAP or Kin each at 0, 0.5, 1, 2 and $4 \mathrm{mg} / \mathrm{l}$.

The proliferated shoot length, number of proliferated shoots and number of leaves/shoot in the first, second and third subcultures were calculated separately. Reculture was done every four weeks for three times.

- Rooting stage: Microshoots resulted from the multiplication stage were transferred to the rooting medium that was supplemented with either IBA or NAA at $0,0.5,1,2$ and $4 \mathrm{mg} / \mathrm{l}$. Rooting percentage, average of root length and root number /plantlet were calculated after four weeks.

- Acclimatization stage: Paulownia tomentosa young plantlets resulted from in vitro culture were washed with a flow of tap water to get rid of medium remains then dipped in a fungicide solution (Rhizolex) $0.5 \mathrm{~g} \mathrm{/} \mathrm{I} \mathrm{for} 30 \mathrm{~min}$. Afterwards, the plantlets were cultured in plastic pots filled with a mixture medium of peat moss: perlit $(2: 1 \mathrm{v} / \mathrm{v})$ and irrigated with water only. For that sake, plantlets were kept inside a plastic tunnel and incubated in a plastic house. After six weeks survival percentage was recorded.

- DNA extraction: DNA was extracted from 250 $\mathrm{mg}$ fresh leaves derived from in vitro raised plants by the CTAB method of Bousquet et al 1990 where DNA quantity is estimated spectrophotometrically.

- Polymerase Chain reaction (PCR) technique: Mullis (1990) discovered the PCR as an enzymatic assay which allows for amplification of a specific DNA fragment from a complex pool of DNA.

- Inter Simple Sequence Repeats (ISSR) technique: ISSR was carried out according to the protocol discovered and performed by Meyer et al (1993).

- Experimental design: A complete randomize design was adopted. In it, each treatment comprised three replicates with three explants per jar for each replication.

- Statistical analysis: All result data were statistically analyzed using the analysis of variance method as reported by Snedecor and Cochran (1980) The differences between means were differentiated by using Duncans range test. (Duncan, 1955).

\section{RESULTS AND DISCUSSION}

\section{- In the Establishment stage}

Results in Table (1) showed that application of clorox at $25 \%$ and $30 \%$ gave higher survival percentage than in other concentrations. Also, sterilization duration periods at 20 and 25 min gave higher survival percentage than other duration periods. Use of Clorox at $30 \%$ with 20 min duration recorded the highest significant survival percentage. 
Table 1. Effect of Colorx concentration and duration period and their interaction during in vitro establishment stage on survival percentage of Paulownia tomentosa explants.

\begin{tabular}{|c|c|c|c|c|c|}
\hline \multirow{2}{*}{$\begin{array}{c}\text { Clorox concentration } \\
(\%)+0.5 \mathrm{~g} / \mathrm{l}\left(\mathrm{HgCl}_{2}\right)\end{array}$} & \multicolumn{5}{|c|}{ Duration period (min) } \\
\hline & $10 \mathrm{~min}$. & $15 \mathrm{~min}$. & $20 \mathrm{~min}$. & $25 \mathrm{~min}$. & Mean \\
\hline 10 & $35.00 \mathrm{~g}$ & $41.67 \mathrm{fg}$ & $43.33 \mathrm{fg}$ & $50.00 f$ & $42.50 \mathrm{E}$ \\
\hline 15 & $45.00 \mathrm{fg}$ & $63.33 e$ & $63.33 e$ & 73.33de & 61.52D \\
\hline 20 & $68.33 e$ & $81.67 \mathrm{~cd}$ & $86.67 \mathrm{bc}$ & $91.67 \mathrm{abc}$ & $82.08 \mathrm{C}$ \\
\hline 25 & $83.33 \mathrm{~cd}$ & $90.00 \mathrm{abc}$ & $95.00 \mathrm{ab}$ & $98.00 \mathrm{a}$ & 91.75B \\
\hline 30 & $90.00 \mathrm{abc}$ & $98.76 a$ & $100.00 \mathrm{a}$ & $95.76 a b$ & 96.08A \\
\hline Mean & $64.33 \mathrm{C}$ & 75.07B & 77.67B & 81.87A & \\
\hline
\end{tabular}

Means having the same letter(s) in each group or interaction had insignificant differences at $5 \%$ level.

These results are in harmony with those found by Ben Bahri and Taoufik (2013) who reported that Paulownia explants were rinsed in sterile distilled water and soaked in $0.1 \%(\mathrm{w} / \mathrm{v}) \mathrm{HgCl}_{2}$ for 5 min. Shtereva et al (2014) immersed them in a $30 \%$ solution of $\mathrm{NaOCl}$ for 15 minutes to sterilize Paulownia seeds.

\section{- In the Multiplication stage}

Results in Table (2) showed that Cytokinin type, concentration and their interaction had significant effects on shoot length at all three subcultures carried out. Kin gave significant shoot length $(7.76,7.57$ and $7.14 \mathrm{~cm})$ in respect order of the three subcultures when compared to BAP (5.40, 5.15 and $4.76 \mathrm{~cm})$. Free cytokinin media showed the tallest shoot length when compared to different concentrations of both BAP and Kin at the different subcultures. Evidently, Kin application at 4 $\mathrm{mg} / \mathrm{l}$ gave significant shoot length $(8.50,8.26$ and $4.76 \mathrm{~cm}$ ) in respect order of the three subcultures when compared to other Kin concentrations and all BAP concentrations.

Table 2. Effect of type and concentration of cytokinin and their interaction on shoot length $(\mathrm{cm})$ of Paulownia tomentosa during in vitro multiplication stage for three individual consequtive subcultures.

\begin{tabular}{|c|c|c|c|c|c|c|}
\hline \multirow{2}{*}{$\begin{array}{c}\text { Cytokinin } \\
\text { Type }\end{array}$} & \multicolumn{6}{|c|}{ Concentration (mg/l) } \\
\hline & 0 & 0.5 & 1 & 2 & 4 & Mean \\
\hline \multicolumn{7}{|c|}{ Subculture1 } \\
\hline BAP & $7.23 d$ & $5.38 e$ & $5.41 e$ & $4.53 f$ & $4.46 f$ & $5.40 \mathrm{~B}$ \\
\hline Kin & $7.23 d$ & $7.61 \mathrm{c}$ & $7.41 \mathrm{~cd}$ & $8.03 b$ & $8.50 a$ & 7.76A \\
\hline Mean & 7.23A & $6.49 B$ & 6.41BC & $6.28 \mathrm{C}$ & $6.48 \mathrm{BC}$ & \\
\hline \multicolumn{7}{|c|}{ Subculture 2} \\
\hline BAP & $7.24 \mathrm{c}$ & $5.12 d$ & $5.12 d$ & $4.11 \mathrm{e}$ & $4.16 e$ & 5.15B \\
\hline Kin & $7.24 \mathrm{c}$ & $7.39 c$ & $7.22 \mathrm{c}$ & $7.73 b$ & $8.26 a$ & 7.57A \\
\hline Mean & 7.24A & $6.26 \mathrm{~B}$ & 6.17B & $5.92 \mathrm{C}$ & $6.21 \mathrm{~B}$ & \\
\hline \multicolumn{7}{|c|}{ Subculture 3} \\
\hline BAP & $6.47 d$ & $4.70 \mathrm{e}$ & $4.59 \mathrm{e}$ & $3.81 f$ & $3.80 f$ & 4.67B \\
\hline Kin & $6.47 d$ & $6.97 \mathrm{c}$ & $6.90 \mathrm{c}$ & $7.50 \mathrm{~b}$ & $7.87 a$ & 7.14A \\
\hline Mean & 6.47A & $5.83 B$ & $5.74 \mathrm{~B}$ & $5.66 \mathrm{~B}$ & $5.83 B$ & \\
\hline
\end{tabular}

Means having the same letter(s) in each group or interaction had insignificant differences at $5 \%$ level. 
Results in Table (3) highlighted that Cytokinin type, concentration and their interaction possessed significant effects on shoot length at all three subcultures. BAP gave significant leaf number (15.20, 15.87 and 17.53 ) in respect order of the three subcultures when compared to Kin $(12.69,12.64$ and
13.16). However, BAP application at 2 and $4 \mathrm{mg} / \mathrm{l}$ gave significant leaf number (17.33, 18.89 and 20.44) and (18.67, 21.00 and 22.67) in respect order of three subcultures when compared to almost all other BAP concentrations and all Kin concentrations.

Table 3. Effect of type and concentration of cytokinin and their interaction on leaf number of Paulownia tomentosa during in vitro multiplication stage for three individual consequtive subcultures

\begin{tabular}{|c|c|c|c|c|c|c|}
\hline \multirow{2}{*}{$\begin{array}{l}\text { Cytokinin } \\
\text { Type }\end{array}$} & \multicolumn{6}{|c|}{ Concentration (mg/l) } \\
\hline & 0 & 0.5 & 1 & 2 & 4 & Mean \\
\hline \multicolumn{7}{|c|}{ Subculture 1} \\
\hline BAP & $11.78 \mathrm{c}$ & $13.67 c$ & $14.56 \mathrm{bc}$ & 17.33ab & $18.67 a$ & $15.20 \mathrm{~A}$ \\
\hline Kin & $11.78 \mathrm{c}$ & $13.56 \mathrm{c}$ & $12.44 \mathrm{c}$ & $12.78 \mathrm{c}$ & $12.89 \mathrm{c}$ & 12.69B \\
\hline Mean & $11.78 \mathrm{C}$ & 13.61B & 13.50BC & 15.00AB & $15.78 \mathrm{~A}$ & \\
\hline \multicolumn{7}{|c|}{ Subculture 2} \\
\hline BAP & $11.22 \mathrm{c}$ & $13.67 b c$ & $14.56 b$ & $18.89 \mathrm{a}$ & $21.00 \mathrm{a}$ & $15.87 \mathrm{~A}$ \\
\hline Kin & $11.22 \mathrm{c}$ & $12.67 \mathrm{bc}$ & $12.33 \mathrm{bc}$ & $12.89 \mathrm{bc}$ & $14.11 \mathrm{bc}$ & 12.64B \\
\hline Mean & $11.22 \mathrm{C}$ & 13.17B & 13.44B & $15.89 A$ & $17.50 \mathrm{~A}$ & \\
\hline \multicolumn{7}{|c|}{ Subculture 3} \\
\hline BAP & $11.67 d$ & $16.44 b$ & $16.44 b$ & $20.44 a$ & $22.67 a$ & $17.53 \mathrm{~A}$ \\
\hline Kin & $11.67 d$ & $13.44 \mathrm{~cd}$ & $11.11 d$ & $13.44 \mathrm{~cd}$ & $16.11 \mathrm{bc}$ & 13.16B \\
\hline Mean & 11.67D & $14.94 C$ & $13.78 \mathrm{C}$ & 16.94B & $19.39 \mathrm{~A}$ & \\
\hline
\end{tabular}

Means having the same letter(s) in each group or interaction had insignificant differences at $5 \%$ level.

Results in Table (4) indicated that Cytokinin type, concentration and their interaction manifested significant effects on shoot number at all three subcultures. BAP gave significant shoot number $(2.73,2.91$ and 3.58$)$ in respect order of the three subcultures when compared to Kin (1.33, 1.40 and 1.64). However, BAP application at 2 and $4 \mathrm{mg} / \mathrm{l}$ gave significant shoot number $(3.56,3.89$ and $5.00)$ and $(4.22,4.67$ and 5.56) in respect order of three subcultures when compared to the remaining BAP concentration and all Kin concentrations.

These results are in harmony with those found by Taha et al (2008) who reported superiority of
BAP over other cytokinins for multiple shoots formation in Paulownia. Similarly, Ben Bahri and Taoufik (2013) found that shoot proliferation was induced by the mean of MS medium containing different concentrations of BAP (1or $2 \mathrm{mg} / \mathrm{l}$ ) in combination to different type of auxins.

\section{- In the Rooting stage}

Data in Table (5) indicated that effect of auxin type, concentration and their interaction on rooting percentage of Paulownia tomentosa had no show significant difference at all. 
Table 4. Effect of type and concentration of cytokinin and their interaction on shoot number of Paulownia tomentosa during in vitro multiplication stage for three individual consequtive subcultures

\begin{tabular}{|c|c|c|c|c|c|c|}
\hline \multirow{2}{*}{$\begin{array}{c}\text { Cytokinin } \\
\text { Type }\end{array}$} & \multicolumn{6}{|c|}{ Concentration (mg/l) } \\
\hline & 0 & 0.5 & 1 & 2 & 4 & Mean \\
\hline \multicolumn{7}{|c|}{ Subculture 1} \\
\hline BAP & $1.33 \mathrm{~cd}$ & $2.11 b c$ & $2.44 b$ & $3.56 a$ & $4.22 \mathrm{a}$ & $2.73 A$ \\
\hline Kin & $1.33 \mathrm{~cd}$ & $1.22 \mathrm{~d}$ & $1.11 \mathrm{de}$ & $1.44 \mathrm{~cd}$ & $1.56 \mathrm{~cd}$ & $1.33 \mathrm{~B}$ \\
\hline Mean & 1.33B & 1.67B & $1.78 \mathrm{~B}$ & $2.50 \mathrm{~A}$ & $2.89 \mathrm{~A}$ & \\
\hline \multicolumn{7}{|c|}{ Subculture 2} \\
\hline BAP & $1.11 d$ & $2.44 b$ & $2.44 b$ & $3.89 a$ & $4.67 a$ & $2.91 \mathrm{~A}$ \\
\hline Kin & $1.11 \mathrm{~d}$ & $1.11 d$ & $1.33 \mathrm{~cd}$ & $1.44 \mathrm{~cd}$ & $2.00 \mathrm{bc}$ & $1.40 \mathrm{~B}$ \\
\hline Mean & 1.11D & $1.78 \mathrm{C}$ & $1.89 \mathrm{C}$ & 2.67B & 3.33A & \\
\hline \multicolumn{7}{|c|}{ Subculture 3} \\
\hline BAP & $1.44 d$ & $2.89 b$ & $3.00 \mathrm{~b}$ & $5.00 \mathrm{a}$ & $5.56 a$ & $3.58 \mathrm{~A}$ \\
\hline Kin & $1.44 \mathrm{~d}$ & $1.44 d$ & $1.33 \mathrm{~d}$ & $1.67 \mathrm{~cd}$ & $2.33 b c$ & $1.64 \mathrm{~B}$ \\
\hline Mean & 1.44D & $2.17 \mathrm{C}$ & $2.17 \mathrm{C}$ & 3.33B & $3.94 \mathrm{~A}$ & \\
\hline
\end{tabular}

Means having the same letter(s) in each group or interaction had insignificant differences at $5 \%$ level.

Table 5. Effect of auxin type, concentration and their interaction after three subcultures on rooting percentage of Paulownia tomentosa from in vitro rooting

\begin{tabular}{|c|c|c|c|c|c|c|}
\hline Conc.(mg/l) & $\mathbf{0}$ & $\mathbf{0 . 5}$ & $\mathbf{1}$ & $\mathbf{2}$ & $\mathbf{4}$ & Mean \\
\hline Auxin Type & & & & & & \\
\hline IBA & $100 \mathrm{a}$ & $100 \mathrm{a}$ & $100 \mathrm{a}$ & $100 \mathrm{a}$ & $100 \mathrm{a}$ & $\mathbf{1 0 0 A}$ \\
NAA & $100 \mathrm{a}$ & $100 \mathrm{a}$ & $100 \mathrm{a}$ & $100 \mathrm{a}$ & $100 \mathrm{a}$ & $\mathbf{1 0 0} \mathbf{A}$ \\
\hline Mean & $\mathbf{1 0 0} \mathbf{A}$ & $\mathbf{1 0 0} \mathbf{A}$ & $\mathbf{1 0 0} \mathbf{A}$ & $\mathbf{1 0 0} \mathbf{A}$ & $\mathbf{1 0 0} \mathbf{A}$ & \\
\hline
\end{tabular}

Data in Table (6) indicated that auxin type, concentration and their interaction showed significant effects on root length after three subcultures. NAA gave significant root length $(4.33 \mathrm{~cm})$ in respect order when compared to IBA $(4.04 \mathrm{~cm})$.
However, NAA application at $4 \mathrm{mg} / \mathrm{l}$ gave significant root number $(7.26 \mathrm{~cm})$ in respect order when compared to other NAA concentrations and all IBA concentrations without exception.

Table 6. Effect of auxin type, concentration and their interaction after three subculture on root length of Paulownia tomentosa from in vitro rooting

\begin{tabular}{|c|c|c|c|c|c|c|}
\hline Conc.(mg/l) & $\mathbf{0}$ & $\mathbf{0 . 5}$ & $\mathbf{1}$ & $\mathbf{2}$ & $\mathbf{4}$ & Mean \\
Auxin Type & & & & & & \\
\hline IBA & $2.53 \mathrm{~h}$ & $3.77 \mathrm{ef}$ & $3.88 \mathrm{de}$ & $4.24 \mathrm{~d}$ & $5.80 \mathrm{~b}$ & $\mathbf{4 . 0 4 B}$ \\
NAA & $2.53 \mathrm{~h}$ & $3.47 \mathrm{fg}$ & $3.22 \mathrm{~g}$ & $5.16 \mathrm{c}$ & $7.26 \mathrm{a}$ & $\mathbf{4 . 3 3 A}$ \\
\hline Mean & $\mathbf{2 . 5 3 \mathrm { D }}$ & $\mathbf{3 . 6 2 C}$ & $\mathbf{3 . 5 5 C}$ & $\mathbf{4 . 7 0 B}$ & $\mathbf{6 . 5 3 A}$ & \\
\hline
\end{tabular}

Means having the same letter(s) in each column, row or interaction had insignificant differences at $5 \%$ level 
(Paulownia tomentosa)

Data in Table (7) illustrated that auxin type, did not exhibit significant difference. With regards to concentration, at $0.5 \mathrm{mg} / \mathrm{l}$ recorded highest significant root number $(13,83)$. Concerning the interaction between auxin type and concentration, NAA and IBA at $1,0.5 \mathrm{mg} / \mathrm{l}$ gave highest significant values $(14.00,13.89,13.78$ and 12.56$)$ in respect order.

Table 7. Effect of auxin type, concentration and their interaction after three subculture on root number of Paulownia tomentosa from in vitro rooting

\begin{tabular}{|c|c|c|l|l|l|l|}
\hline Conc.(mg/l) & \multicolumn{1}{|c|}{$\mathbf{0}$} & $\mathbf{0 . 5}$ & $\mathbf{1}$ & \multicolumn{1}{|c|}{$\mathbf{2}$} & \multicolumn{1}{|c|}{$\mathbf{4}$} & Mean \\
\hline Auxin Type & & & & & & \\
\hline IBA & $10.78 \mathrm{~b}$ & $13.78 \mathrm{a}$ & $12.56 \mathrm{ab}$ & $12.78 \mathrm{ab}$ & $12.11 \mathrm{~b}$ & $\mathbf{1 2 . 4 0 A}$ \\
NAA & $10.78 \mathrm{~b}$ & $13.89 \mathrm{a}$ & $14.00 \mathrm{a}$ & $11.00 \mathrm{~b}$ & $12.11 \mathrm{~b}$ & $\mathbf{1 2 . 3 6 A}$ \\
\hline Mean & $\mathbf{1 0 . 7 8 D}$ & $\mathbf{1 3 . 8 3 A}$ & $\mathbf{1 3 . 2 8 A B}$ & $\mathbf{1 1 . 8 9 C D}$ & $\mathbf{1 2 . 1 1 B C}$ & \\
\hline
\end{tabular}

Means having the same letter(s) in each column, row or interaction had insignificant differences at $5 \%$ level.

Ben Bahri and Taoufik (2013) reported that the addition of $0.5 \mathrm{mg} / \mathrm{I}$ IBA to MS medium gave $100 \%$ rooting percentage of Paulownia tormentosa shoots. Shtereva et al (2014) stated that $1 \mathrm{mg} / \mathrm{I}$ IBA gave $100 \%$ rooting in Paulownia tormentosa and $99.4 \%$ in Paulownia elongata. Roy (2015) mentioned that Paulownia shoots rooted well in half strength MS supplemented with $2.0 \mathrm{mg} / \mathrm{l}$ NAA.

\section{- In the Acclimatization stage}

Paulownia tomentosa acclimatization of in vitro plantlets was highly successful with an $85.93 \%$ survival rate after four weeks when placed in a greenhouse (Plate 1). Similarly, Zayova (2011) reported that the highest survival percentage $(100 \%)$ was provided in plants grown on a mixture of peat: perlite in a 2:1 ratio in a greenhouse. Roy (2015) mentioned that regenerated plantlets were successfully acclimatized in poly bags containing a mixture of soil and compost in 2:1 ratio. About $90 \%$ plantlets survived under open field conditions.

\section{- Assessment of genetic stability using ISSR markers}

All three primers produced clear and reproducible bands (Plate 2). All banding profiles from micropropagated plants were monomorphic. The three ISSR primers produced 22 distinct and scorable bands in the size range of $460 \mathrm{bp}$ to $18660 \mathrm{bp}$ (Table 8). The number of scorable bands for each primer varied from 6 (ISSR-HB12) to 9 (ISSRHB13). Similar results have been reported by Martin et al (2004) in almond, Joshi and Dhawan (2007) in Swertia chirayita, Sreedhar et al (2007) in Vanilla planifolia and Abd elrazik (2012) in Paulownia tomentosa. Earlier, Reynoird et al (1993) did not observe any phenotypic variations during vegetative and reproductive phases among the regenerates of Gerbera. 


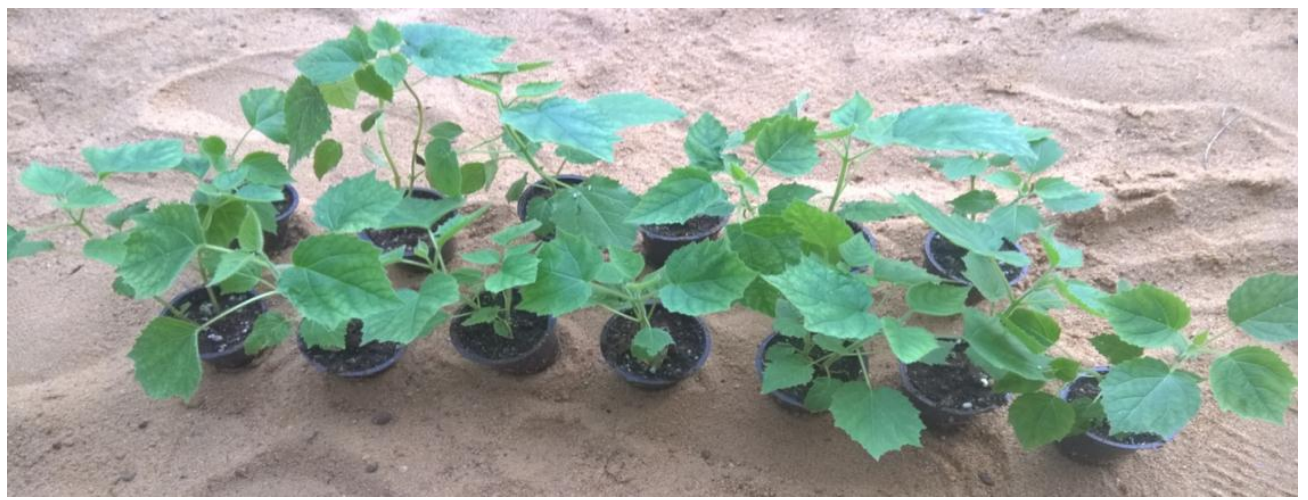

Plate 1. Acclimatization of in vitro produced plantlets of Paulownia tomentosa
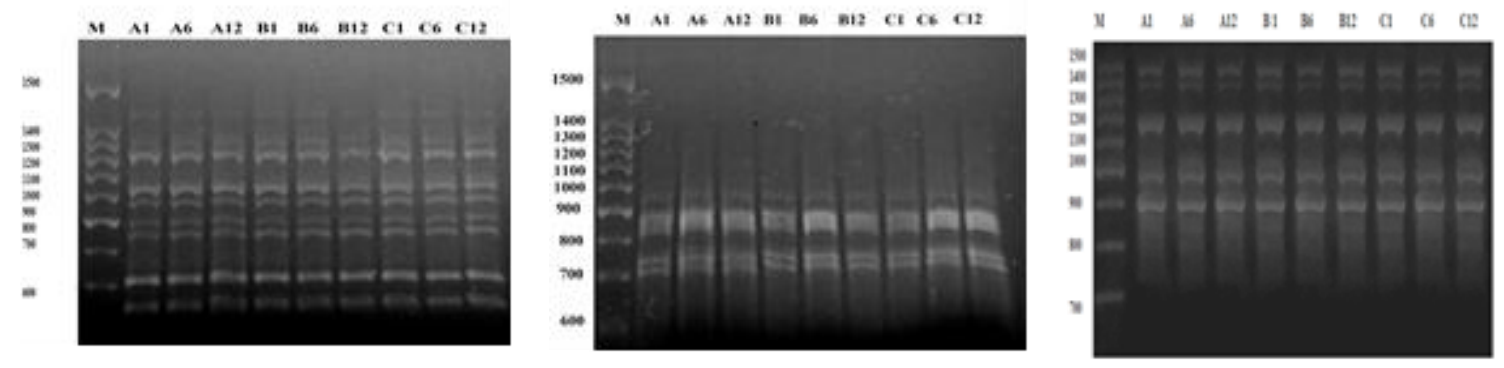

Plate 2. DNA bands generated for Paulownia tomentosa by ISSR primers (HB 11 - HB 12 - HB 13) with 9 samples $(M=$ Marker, $A 1=$ Mother plant $A$, A6= explant after 6 subcultures , A 12= explant after 12 subcultures , B1= Mother plant B , B 6= explant after 6 subcultures , B 12= explant after 12 subcultures , C1= Mother plant C , C $6=$ explant after 6 subcultures , C 12= explant after 12 subcultures ).

Table 8. Summary of number of band patterns resulting from ISSR electrophoretic of nine samples of Paulownia tomentosa

\begin{tabular}{|c|c|c|c|}
\hline Primer & $\begin{array}{c}\text { No. of } \\
\text { bands }\end{array}$ & $\begin{array}{c}\text { Lowest } \\
\text { length } \\
(\approx \text { bp) }\end{array}$ & $\begin{array}{c}\text { Highest } \\
\text { length } \\
(\approx \text { bp) }\end{array}$ \\
\hline HB 11 & 7 & 1350 & 11160 \\
HB 12 & 6 & 850 & 3510 \\
HB 13 & 9 & 460 & 18660 \\
\hline
\end{tabular}

\section{CONCLUSIONS}

- Successful micropropagation through tissue culture of Paulownia tomentosa can be obtained from: use of clorox at $30 \%$ for 20 min. as a sterilization agent. Kin at $4 \mathrm{mg} / \mathrm{l}$ can be used to obtain tallest shoots, but greatest multiplication rate and highest number of leaves could be achieved using BA at 2 and $4 \mathrm{mg} / \mathrm{l}$. NAA at $1 \mathrm{mg} / \mathrm{l}$ was appropriate to ob- tain highest root number per shoot and a mixture of peat moss: perlite $(2: 1 \mathrm{v} / \mathrm{v})$ under plastic tunnel was suitable to achieve high survival rate (85.93\%) of resultant plantlets from the acclimatization stage.

-The genetic stability of in vitro raised Paulownia tomentosa clones was assessed by inter-simple sequence repeats (ISSRs) markers. All banding profiles from resultant micropropagated plantlets were monomorphic and similar to those of the mother plant, indicating $100 \%$ similarity.

\section{REFERENCES}

Abd el razik A.B. 2012. Evaluation of the genetic stability of in vitro -propagated Paulownia tomentosa using DNA - based markers. Egyptian J. of Genetic and Cytology 41, 151-161.

Akyildiz M.H. and Shahin H.K. 2010. Some technological properties and uses of Paulownia tomentosa Steud.) wood. J. of Environmental Biology 31, 351-355. 
(Paulownia tomentosa)

Ben Bahri N. and Taoufik B. 2013. In vitro propagation of a forest tree Paulownia tomentosa (Thumb.) Steud. - A valuable medicinal tree species. Albanian J. Agric. Sci., 12(1), 37 42.

Bergmann B.A. and Moon H.K. 1997. In vitro adventitious shoot production in Paulownia. Plant Cell Rep 16, 315-319.

Bergmann B.A. 1998. Propagation method influences first year field survival and growth of Paulownia. New Forests 16, 251-264.

Bousquet, J. Simon L. and Lalonde M. 1990. DNA amplification from vegetative and sexual tissues of trees using polymerase chain reactions. Can. J. For. Res., 20, 254-257.

Carpenter S.B. 1997. This "princess" heals disturbed land. American Forest, 83, 22-23.

Chunchukov A. and Yancheva S. 2015. Micropropagation of Paulownia species and hybrids. Annuaire de I Université de Sofia, 100, 223230.

Duncan D.B. 1955. Multiple range and multiple Ftests. Biometrices, 11, 1-42

Ipekci Z., Altinkut A., Kazan K. BaJrovic K. and Gozukirmizi N. 2001. High frequency plant regeneration from nodal explants of Paulownia elongata. Plant Biology, 3, 113-115.

Joshi P. and Dhawan V. 2007. Assessment of genetic fidelity of micropropagated Swerita chirayita plantlets by ISSR marker assay. Boil. Plant, 51, 22-26.

Litwinczuk W. and Bochnia E. 2012. Development of royal paulownia (Paulownia tomentosa Steud.) in vitro shoot cultures under the influence of different saccharides. Acta Scientiarum Polonorum- Hortorum Cultus 11(2), 13-19.

Lobna, S.T. Ibrahim M.M.S. and Farahat M.M. 2008. A micropropagation protocol of Paulownia kowakamii through in vitro culture technique. Australian J. of Basic and Applied Sci., 2(3), 594-600.

Markovic M., Vilotic D. and Popovic M. 2013. Propagation of Paulownia elongata S. Y. Hu by axillary shoots. Propagation of Ornamental Plants, 13(2), 73-77.

Martin M., Sarmento D. and Olivera M.M. 2004. Genetic stability of micropropagated almond plantlets, as assessed by RAPD an ISSR markers. Plant Cell Rep., 23, 492- 496.

Meyer W. Mitchell T.G. Freedman E.Z. and Vilgays R. 1993. Hybridization probes for conventional DNA fingerprinting used as single primers in the polymerase chain reaction to distinguish strains of Cryptococcus neoformes. J. of Clinical Microbiology, 31, 2274-2280.
Mullis K. B. 1990. The unusual origins of the polymerase chain reaction. Scientific American. 262(4), 56-61.

Murashige T. and Skoog F. 1962. A revised medium for rapid growth and bioassays with tobacco tissue culture. Physiol. Plant, 15, 473497.

Puxeddu M. Marras G. and Murino G. 2012. Paulownia tree planting in Sardinia(Italy) and its evaluation for agroforestry systems and sustainable land use. J. of Environmental Sci. and Engineering, B 1, 1192-1195.

Reynoird J.P. Chriqui, D., Noin M., Brown S. and Marie D. 1993. Plant regeneration from in vitro leaf culture of several Gerbera species. Plant Cell Tissue Organ Cult., 33, 203-210.

Rout G.R. Reddy G.M. and Das P. 2001. Studies on in vitro clonal propagation of Paulownia tomentosa Steud. and evaluation of genetic fidelity through RAPD marker. Silvae Genetica, 50(5/6), 208-212.

Roy P.K. 2015. In Vitro plant regeneration of Paulownia tomentosa (Thunb.) Steud. From shoot tip and leaf segment. Bangladesh J. Bot. 44(3), 459-463.

Shtereva L., Roumiana V., Tania K. and Boris K. 2014. Micropropagation of six Paulownia genotypes through tissue culture. J. of Central European Agric., 15(4), 147-156.

Snedecor G.W. and Cochran W.G. 1980. Statistical Methods. $7^{\text {th }}$ Ed. lowa State Univ. Press, Ames. lowa, U.S.A. 507 p.

Sreedhar R., Venkatachalam V.L. and Bhagyalakshmi N. 2007. Genetic fidelity of long term micropropagated shoot cultures of vanilla (Vanilla planifolia Andrews) as assessed by molecular markers. Biotechnol. J., 2, 10071013.

Taha L.S., Ibrahim M.M.S. and Farahat M.M. 2008. A Micropropagation Protocol of Paulownia kowakamii through in vitro culture technique. Australian J. of Basic and Applied Sci., 2, 594-600.

Zayova E. 2011. In vitro rooting of cloned paulownia (Paulownia elongata) plants. Rasteniev'dni Nauki, 48(4), 417-421.

Zayova E., Stoeva D., Petrova and Dimitrova L.M. 2011. Micropropagation of paulownia (Paulownia elongata). Rasteniev'dni Nauki, 48(4), 422-425.

Zhu Z.H., Chao C.J., Lu X.X. and Xiong Y.G. 1986. Paulownia in China cultivation and utilization. Asian Network for Biol. Sci. and Inter. Dev. Res. Centre, Singapore, pp. 1-65. 


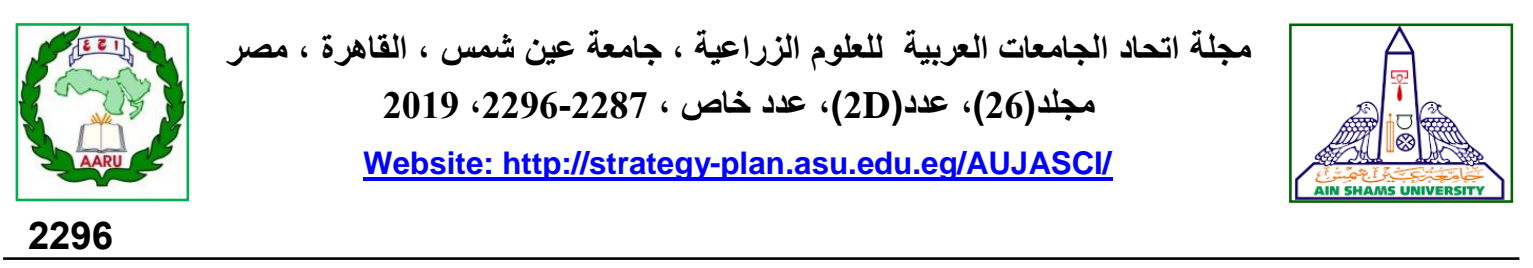

الاكثثار الدقيق وتقييم الثبات الوراثي للباولونيا (Paulownia tomentosa)

[166]

كريم محمد حسن $1{ }^{1}$ - عبدالعزيز محمد حسنى1 - محمد هويدى محمود1 - أشرف بكرى عبد الرازق 2

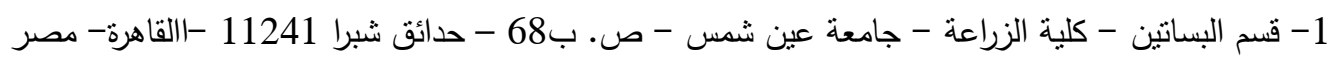

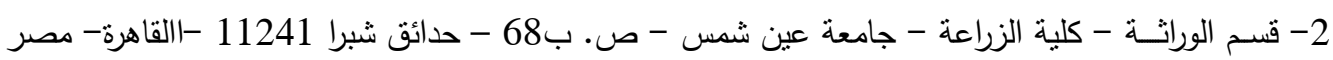

*Corresponding author: karim_hassan84@yahoo.com

Received 1 August, 2018

Accepted 29 August, 2018

كلوراكس لمدة 20 دقيقة. تم الحصول على أطول الأفرخ وأكبر عدد للأوراق مع المعاملة 2,4 ملجة دألتر

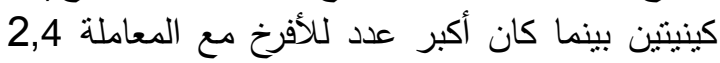

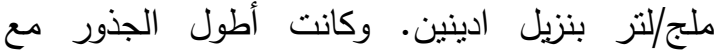

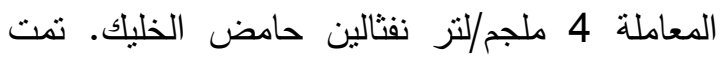
اقلمة النباتات الناتجة من زراعة الانسجة عن طريق

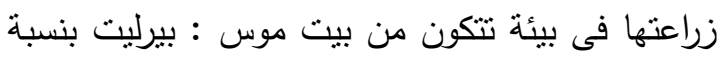

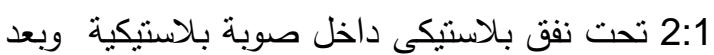
63 اسابيع نم تقدير نسبة البقاء لهذه النباتات وكانت \%85.93

وتم تقييم الثبات الوراثي للنباتات الناتجة من زراعة الانسجة بتقنية التتابعات البسيطة البينية المتكررة لناتية

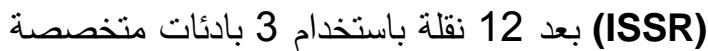
(HB11, HB12 , HB13) ثابتة وراثية ولم يحدث بها اى تغيرات وراثية على مدار 12 نقلة.

الكلمات الدالة: زراعة الأنسجة، الباولونيا، تقييم الثبات الوراثي

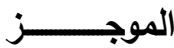

تم اجراء التجربة بمعمل زراعة الانسجة بمركز الهندسة الوراثية - قسم الوراثة - كلية الزراعة جامعة الأدة عين شمس- مصر فى الفترة من 2013 الى الى 2018. هدفت الدراسة للوصول الى افضل المعاملات لأكثار

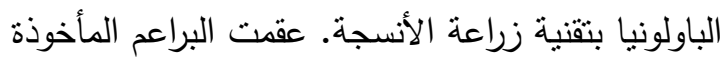

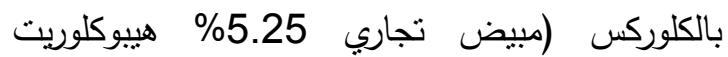
الصوديوم) بتركيزات 10 و 15 , 20 , 25 و 30 (25 باستخدام فترات تعرض مختلفة (10 , 15 و 10 و 20 و 25 و 25 دقيقة). زرعت البراعم المعقمة على بيئة ميوراشيج

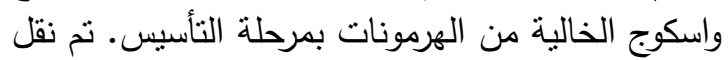

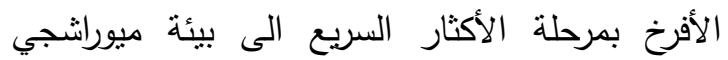
واسكوج المحتوية على نركيزات مختلفة لكل من البنزيل البنيل ادينين والكينيتين (0 و 0.5 و 1 و 2 و 4 ملجم/لتنز ). وكانت بيئة التجذير مكونة من 4/3 قوة بيئة ميوراشيج

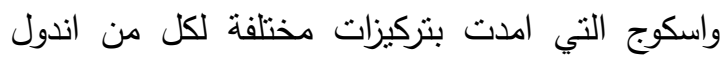
حامض البيوتريك ونفتالين حامض الخليك (0و 0.5 و 1 و و و ملجم/لتزر). أتنتت النتائج أن أقل نسبة

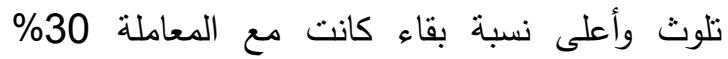

